\title{
PENGEMBANGAN POTENSI MASYARAKAT MELALUI INDUSTRI KREATIF SEBAGAI RINTISAN DESA WISATA DI DESA KUNDISARI, KEDU, TEMANGGUNG
}

\author{
Basnendar Herryprilosadoso \\ Jurusan Desain \\ Fakultas Seni Rupa dan Desain ISI Surakarta \\ Email: basnendart@yahoo.com
}

\begin{abstract}
Abstrak
Desa Kundisari merupakan salah satu daerah yang berada di Kecamatan Kedu, Kabupaten Temanggung Proinsi Jawa Tengah yang memiliki beragam potensi di bidang kesenian yang terdiri dari 4 (empat) potensi, yaitu kesenian kuda lumping, gerabah, seni musik dangdut, sholawatan dan rebana. Selain potensi seninya dengan permukaan wilayahnya dengan dataran tinggi sangat berpotensial dijadikan destinasi pariwisata. Prioritas permasalahan yang ada, yaitu : 1) Metode pendampingan dalam pengembangan dan pengelolaan seni kerajinan berbasis bambu dan batik eco print sebagai cinderamata (souvenir); 2) Metode pendampingan dalam pengembangan dan pengelolaan manajemen sumber daya manusia untuk menyusun rintisan desa wisata kreatif; dan 3) Metode pendampingan dalam pengembangan untuk perancangan Environment Graphic Design. Tahapan dan proses pengabdian kepada masyarakat tematik ini terdiri dari 3 (tiga) tahapan besar, yaitu : Tahapan Identifikasi Masalah (Envisioning Phase), Tahapan Perencanaan (Planning Phase), dan Tahapan Desain/Rancangan (Developing Phase) dengan melalui teknis pelatihan, pendampingan, dan workshop bagi warga masyarakat Desa Kundisari.

Sinergitas pihak kampus dan akademisi dalam mendukung program pelatihan kepada masyarakat dalam rangka pengembangan potensi desa di bidang industri kreatif sangat diperlukan, khususnya pelatihan teknologi tepat guna yang nantinya bisa langsung diterapkan oleh warga masyarakat desa.
\end{abstract}

Kata kunci: Potensi Desa, Pelatihan Kerajinan, Industri Kreatif, Desa Wisata Kundisari.

\begin{abstract}
Kundisari Village is one of the areas in Kedu, Temanggung, Central Java Province which has a variety of potentials in the arts consisting of 4 (four) potentials, namely kuda lumping, pottery, dangdut music art, sholawatan and tambourine. In addition to its artistic potential with the surface of its territory with a plateau is very potential to be a tourism destination.Priority problems that exist, namely: 1) Methods of assistance in the development and management of bamboo and batikbased handicraft arts as souvenirs (souvenirs); 2) Assistance methods in the development and management of human resource management to develop creative tourism village pilot projects; and 3) Assistance methods in development for designing Environmental Graphic Design. The stages and process of dedication to this thematic community consists of 3 (three) major stages, namely: the Phase of Identification Problems (Envisioning Phase), the Planning Phase (Planning Phase), and the Design / Design Stages through the technical training, mentoring, and workshops for residents of the Kundisari. Synergy between the campus and academics in supporting training programs for
\end{abstract}




\section{Abdi Seni Jurnal Pengabdian Kepada Masyarakat}

the community in the context of developing village potential in the field of creative industries is very much needed, especially training in appropriate technology which can later be directly applied by villagers.

Keywords: Village Potential, Handicraft Training, Creative Industries, Kundisari Tourism Village

\section{PENDAHULUAN}

\section{A. Latar Belakang}

Wilayah perdesaan yang ada di Indonesia tidak luput dari banyaknya kawasan wisata yang dapat dikembangkan untuk membangkitkan ekonomi masyarakat perdesaan itu sendiri, dalam hal ini wilayah Indonesia sangat meyakinkan untuk mewujudkan wilayah perdesaan yang memiliki daya tarik tersendiri terhadap kawasan wisata yang di miliki di beberapa wilayah yang ada di Indonesia yang dapat dikembangkan sebagai desa wisata. Kawasan desa yang memiliki daya tarik terhadap wisatawan lokal, maupun non-lokal yang mengunjungi kawasan tersebut setidaknya dapat memberikan kenyamanan bagi para wisatawan, seperti halnya infrastruktur yang bagus (jalan), dan ketersedian transportasi, sehingga lebih mempermudah para wisatawan mengunjungi tempat-tempat wisata yang ada di desa-desa, baik itu didesa yang pedalaman maupun tidak. Untuk itu perlu mengembangkan perencanaan yang akan membangunan desa menjadi desa wisata.

Pariwisata menurut jenisnya dikelompokkan menjadi tiga bagian, yaitu : culture, nature, dan adventure. Culture melingkupi seluruh hasil cipta daya manusia seperti seni (teater, tarian, musik) crafts, festival, museum, arsitektur, agama, kesehatan dan lain-lain. Nature di turisme dipandang sebagai segala macam aktivitas yang berhubungan dengan alam. Jenis adventure yang bersifat lebih personal, dimana terdapat penggabungan antara culture dan nature, namun ditambahkan dengan sisi tantangan dan petualangan (Sapta Nirwandar, 2014 : 157).

Wilayah desa di Kabupaten Temanggung sangat berpotensial dijadikan destinasi pariwisata. Permukaan wilayah Kabupaten Temanggung termasuk dataran tinggi, dengan topografi semacam itu, wilayah Kabupaten Temanggung memililki permukaan yang sangat beragam ditinjau dari ketinggian dan luas wilayah/kawasan. Sebagian wilayah Kabupaten berada pada ketinggian $500 \mathrm{~m}$ $1450 \mathrm{~m}(24,3 \%)$, luasan areal ini merupakan daerah lereng Gunung Sindoro dan Sumbing yang terhampar dari sisi selatan, barat sampai dengan utara wilayah. Kabupaten Temanggung memiliki dua buah gunung, yaitu Gunung Sindoro dan Gunung Sumbing, dengan stadium erupisnya mulai muda sampai tua.

Desa Kundisari merupakan salah satu daerah yang berada di Kecamatan Kedu, yang menjadi bagian wilayah dan pemerintahan Kabupaten Temanggung ProvinsiJawa Tengah yang memiliki beragam potensi di bidang kesenian yang terdiri dari 4 (empat) potensi, yaitu kesenian kuda lumping, gerabah, seni musik dangdut, sholawatan dan rebana. Selain potensi seninya dengan permukaan wilayahnya dengan dataran tinggi sangat berpotensial dijadikan destinasi pariwisata. Beragam potensi yang dimiliki di desa Kundisari sangat beragam namum dalam perjalanan waktu belum dikelola secara maksimal sehingga tidak berkermbang. Diperlukan strategi dan tata kelola yang sesuai dengan karakter dan kondisi baik wilayah dan sosial kemasyarakatan untuk pengembangan seni tradisi yang ada di desa Kundisari, serta sebagai rintisan desa wisata di Dusun Nyamplung.

\section{B. Rumusan Masalah}

Permasalahan yang ada di Desa Kundisari yang sesuai dengan program pembangunan desa untuk meningkatkan dan mengembangkan potensi yang dimiliki. Desa Kundisari yang membutuhkan beberapa kepakaran bidang riset dan ilmu pengetahuan yang berbeda. Sebagai ilustrasi untuk 
prioritas permasalahan dari aspek pengembangan potensi desa, misalnya belum memaksimalkan sumber daya alam, penegembangan kerajinan berbasis potensi desa, rintisan desa wisata di rintisan desa wisata di Dusun Nyamplung, Desa Kundisari, dan permasalahan yang lainnya. Prioritas permasalahan dapat dibagi dalam 3 (tiga) aspek yaitu:

1. Pengembangan Seni Kerajinan Potensi Desa Berbasis Industri Kreatif.

Seperti bidang industri kreatif yang bisa diterapkan di desa Kundisari, pemberian pelatihan ketrampilan seni kerajinan dengan memanfaatkan potensi yang ada, misalnya banyaknya pohon bambu yang tersebar di berbagai wilayah desa, dengan seni kerajinan berbasis bambu tersebut berfungsi sebagai penunjang rintisan desa wisata nantinya.

2. Penyusunan Pendukung Rintisan Desa Wisata Kreatif.

Kendala mengenai kurang adanya kesadaran masyarakat akan potensi diri yang bisa mendukung mewujudkan rintisan desa wisata kreatif di Desa Kundisari.

3. Peningkatan Sarana dan Prasarana Pendukung Desa Wisata.

Belum adanya fasilitas Environment Graphic Design, berupa sign system, papan informasi destinasi, petunjuk lokasi, dan papan informasi lainnya, penataan objek lokasi wisata yang belum maksimal, dan fasilitas peralatan, seperti peralatan pendukung untuk menunjang ketrampilan seni kerajinan, properti seni pertunjukan, dan fasilitas penunjang desa wisata lainnya.

\section{Tinjauan Desa Wisata dan Potensi Wilayah Desa Kundisari, Kabupaten Temanggung}

\section{Desa Wisata sebagai Destinasi Unggulan Pariwisata}

Indonesia memilikibanyak keanekaragaman potensi wisata. Daya tarik wisata yang telah dibangun dari daerah-daerah mampu menarik wisatawan untuk hadir berekreasi. Menurut undang-undang no. 10 tahun 2009 daya tarik wisata bisa dijelaskan sebagai segala sesuatu yang mempunyai keunikan, kemudahan dan nilai yang berwujud keanekaragaman, kekayaan alam, budaya dan hasil buatan manusia yang menjadi sasaran atau kunjungan wisatawan. Keberagaman keunikan yang dimiliki oleh setiap daerah yang ada di Indonesia menjadikan daya tarik wisatawan untuk datang menyaksikan dan menikmatinya. Salah satu tempat yang sedang berkembang yaitu desa wisata yang masih mempunyai nuansa pedesaan. Menurut Oka Yoeti (1996 : 76), desa wisata adalah sebuah kawasan pedesaan yang memiliki beberapa karakteristik khusus untuk menjadi daerah tujuan wisata. Di kawasan ini, penduduknya masih memiliki tradisi dan budaya yang relatif masih asli. Selain itu, beberapa faktor pendukung seperti makanan khas, sistem pertanian dan sistem sosial turut mewarnai sebuah kawasan desa wisata. Di luar faktor-faktor tersebut, alam dan lingkungan yang masih asli dan terjaga merupakan salah satu faktor terpenting dari sebuah kawasan tujuan wisata.

Dalam Peraturan Menteri Kebudayaan dan Pariwisata Nomor : PM.26/UM.001/MKP/2010 Tentang Pedoman Umum Program Nasional Pemberdayaan Masyarakat (PNPM) Mandiri. Desa Wisata adalah suatu bentuk integrasi antara atraksi, akomodasi dan fasilitas pendukung yang disajikan dalam suatu struktur kehidupan masyarakat yang menyatu dengan tata cara dan tradisi yang berlaku. Menurut Priasukmana dan Mulyadin (2001 : 56, 72), Desa Wisata merupakan suatu kawasan pedesaan yang menawarkan keseluruhan suasana yang mencerminkan keaslian pedesaaan baik dari kehidupan sosial ekonomi, sosial budaya, adat istiadat, keseharian, memiliki arsitektur bangunan dan struktur tata ruang desa yang khas, atau kegiatan perekonomian yang unik dan menarik serta mempunyai potensi untuk dikembangkannya berbagai komponen kepariwisataan, misalnya atraksi, akomodasi, makanan-minuman, cinderamata, dan kebutuhan wisata lainnya. Penetapan suatu desa dijadikan sebagai desa wisata harus memenuhi 
persyaratan-persyaratan, antara lain sebagai berikut:

a. Aksesibilitasnya baik, sehingga mudah dikunjungi wisatawan dengan menggunakan berbagai jenis alat transportasi.

b. Memiliki obyek-obyek menarik berupa alam, seni budaya, legenda, makanan lokal, dan sebagainya untuk dikembangkan sebagai obyek wisata.

c. Masyarakat dan aparat desanya menerima dan memberikan dukungan yang tinggi terhadap desa wisata serta para wisatawan yang datang kedesanya.

d. Keamanan di desa tersebut terjamin.

e. Tersedia akomodasi, telekomunikasi, dan tenaga kerja yang memadai.

f. Beriklim sejuk atau dingin.

g. Berhubungan dengan objek wisata lain yang sudah dikenal oleh masyarakat luas.

Desa wisata sebagai bagian dari pariwisata dapat dimaknai sebagai suatu bentuk integrasiantara atraksi, akomodasi dan fasilitas pendukung yang disajikan dalam suatu struktur kehidupan masyarakat yang menyatu dengan tata cara dan tradisi yang berlaku di suatu desa. Definisi dari desa wisata adalah suatu bentuk integrasi antara atraksi, akomodasi dan fasilitas pendukung yang disajikan dalam suatu struktur kehidupan masyarakat yang menyatu dengan tata cara dan tradisi yang berlaku (Nuryanti, 1993). Menurut Nuryanto Adhi (2016 : 3). Terdapat dua konsep yang utama dalam komponen desa wisata, yaitu akomodasi dan atraksi. Akomodasi maksudnya adalah sebagian dari tempat tinggal para penduduk setempat dan atau unit-unit yang berkembang atas konsep tempat tinggal penduduk. Sedangkan atraksi meliputi seluruh kehidupan keseharian penduduk setempat beserta setting fisik lokasi desa yang memungkinkan berintegrasinya wisatawan sebagai partisipasi aktif seperti : kursus tari, bahasa dan lain-lain yang spesifik.

Sedangkan Edward Inskeep, dalam bukunya Tourism Planning An Integrated and Sustainable Development Approach, (1991:166) memberikan definisi : Village Tourism, where small groups of tourist stay in or near traditional, often remote villages and learn about village life and the local environment, artinya bahwa wisata pedesaan dimana sekelompok kecil wisatawan tinggal dalam atau dekat dengan suasana tradisional, sering di desa-desa yang terpencil dan belajar tentang kehidupan pedesaan dan lingkungan setempat.

Selain berbagai keunikan tersebut, kawasan desa wisata juga dipersyaratkan memiliki berbagai fasilitas untuk menunjangnya sebagai kawasan tujuan wisata. Berbagai fasilitas ini akan memudahkan para pengunjung desa wisata dalam melakukan kegiatan wisata. Fasilitas-fasilitas yang seharusnya ada disuatu kawasan desa wisata antara lain : sarana transportasi, telekomunikasi, kesehatan, dan akomodasi. Khusus untuk sarana akomodasi, desa wisata dapat menyediakan sarana penginapan berupa pondok-pondok wisata (Home Stay) sehingga para pengunjung dapat merasakan suasana pedesaan yang masih asli. Fasilitas di objek wisata, juga dibutuhkan fasilitas penunjang, misal papan penunjuk arah, papan informasi, peta lokasi dan fasilitas lainnya. Sebuah obyek wisata adalah tempat yang membutuhkan EGD (Environment Graphic Design), karena didalamnya terdapat suatu objek dimana tidak hanya informasi yang diperlukan untuk menjelaskan apa yang disana, melainkan suasana seperti apa objek bisa bertahan, dan memberikan kesan pada pengunjung bagaiman objek tersebut dapat hidup pada jamannya (Herryprilosadoso, $2007: 20)$.

\section{Kondisi dan Wilayah Kabupaten Temanggung}

Kabupaten Temanggung terletak di tengahtengah Propinsi Jawa Tengah yang memiliki sifat iklim tropis dengan dua musim yaitu musim kemarau antara bulan April sampai dengan September dan musim penghujan antara bulan Oktober sampai dengan Maret dengan curah hujan tahunan pada umumnya tinggi. Kabupaten Temanggung memiliki dua buah gunung, yaitu Gunung Sindoro dan Gunung Sumbing, yaitu stadium erupisnya mulai muda sampai 
tua. Obyek wisata yang ada di wilayah kabupaten Temanggung, antara lain yaitu : Sumbing Sindoro, Pikatan Water Park, Wanawisata Jumprit, Candi Pringapus, Prasasti Gondosuli,Taman, Rekreasi Kartini, Monumen Meteorit, Monumen Bambang Sugeng, Curug Lawe, Curug Trocoh (Surodipo), Agrowisata, Goa Wonotirto, Goa Lawa, dan Wisata Tradisi lainnya.

Kabupaten Temanggung mempunyai potensi kerajinan yang apabila dikembangkan dapat menjadi komoditi unggulan yang siap bersaing dipasar regional, nasional bahkan luar negeri. Untuk mengetahui jenis produk tersebut maka berikut diperkenalkan beberapa jenis produk kerajinan dalam bentuk diskripsi. Produk unggulan dari Kabupaten Temanggung, beragam dan sangat potensial untuk dikembangkan. Produk unggulan tersebut anatara lain : relief tembaga dan kuningan, pakaian kesenian, anyaman mendong, gerabah tanah, kerajinan bambu, kerajinan kayu, dan anyaman pelepah pisang.

\section{Gambaran Umum Wilayah Desa Kundisari}

Desa Kundisari merupakan salah satu daerah yang berada di Kecamatan Kedu, Kabupaten Temanggung Provinsi Jawa Tengah. Desa Kundisari berada pada ketinggian $700 \mathrm{~m}$ dpl, berjarak $6 \mathrm{~km}$ dari ibukota kecamatan Kedu dan $12 \mathrm{~km}$ dari ibukota kabupaten. Desa Kundisari mencakup daerah seluas 140,01 ha yang terbagi atas lahan sawah dan lahan nonsawah. Lahan nonsawah dipergunakan untuk bangunan/ pekarangan, ladang/tegalan, hutan rakyat, perkebunan negara/rakyat dan lainnya. Asal usul Desa Kundisari semula terdiri dari tiga desa :

a. Desa Guntursari terdiri dari Dukuh. Kamal, Ngemplak dan Dukuh Guntursari.

b. Desa Kebonagung meliputiDukuh Mrian Kulon, Mrian Wetan, dan Dukuh Nyamplung.

c. Desa Munding meliputi Dukuh Munding Kidul dan Munding Lor.

Pada tahun 1929 dari desa tersebut dijadikan satu desa pembaharuan yang dinamakan
Desa Kundisari yang artinya kebanyakan dukuhdukuh tersebut banyak yang mata pencaharian penduduknya membuat grabah,genting, dan berkakas rumah tangga. Yang diistilahkan orang yang menerjakan dari tanah liat dinamakan Kundi atau Pekunden. Namun meskipun penduduknya banyak pekunden (kundi) taraf hidup mereka bisa leih baik sampai sekarang.

Desa Kundisari merupakan salah satu desa dari 14 desa diwilayah kecamatan Kedu Kabupaten Temanggung yang terletak dilereng Sumbing dengan ketinggian $\pm 632 \mathrm{~m}$ diatas permukaan air laut. Desa Kundisarimemiliki 8 dusun, 8 rukun warga (RW) dan 32 rukun tetangga (RT). Mayoritas mata pencaharian penduduk adalah sebagai petani, pedagang dan pengrajin gerabah. Selain itu terdapat pula pengrajin tas dari bahan plastik. Desa Kundisari terdapat 1 PAUD, 1 TK, 2 SD dan 1 MI. Di sekolah tersebut terdapat ekstrakurikuler tari, drumband, MTQ, rebana dan kuda lumping.

Iklim di desa Kundisari termasuk iklim sedang (tidak panas dan tidak dingin). Sumber air kurang memadahi pada daerah dataran tinggi. Penduduk di Desa Kundisari sangat religius, namun juga rawan akan pencurian. Kebanyakan kegiatan dikelola oleh Pemuda Anshor (NU), karena Karang Taruna yang pasif. Ibu-ibu PKK di desa Kundisari termasuk aktif. Desa Kundisari memiliki website yang dikelola oleh perangkat desa. Selain itu, desa ini juga sedang mengembangkan Wisata Edukasi Pelatihan Pembuatan Gerabah. Desa Kundisari memiliki beragam potensi di bidang kesesenian yang ada dan dimiliki, yang terdiri 4 (empat) potensi, seperti : kerajinan gerabah, kesenian kuda lumping, sholawatan dan rebana, serta seni musik dangdut.

\section{Metode Pengabdian Kepada Masyarakat}

Metode yang digunakan secara umum dalam pengabdian kepada masyarakat di Desa Kundisari melalui pendampingan Iptek (Ilmu Pengetahuan dan Teknologi). Pendampingan adalah pekerjaan yang dilakukan oleh fasilitator atau pendamping masyarakat dalam berbagai kegiatan 
program. Fasilitator juga seringkali disebut fasilitator masyarakat (community facilitator/CF) karena tugasnya lebih sebagai pendorong, penggerak, katalisator, motivator masyarakat, sementara pelaku dan pengelola kegiatam adalah masyarakat sendiri.

Pendampingan sebagai suatu strategi yang umum digunakan oleh pemerintah dan lembaga non profit dalam upaya meningkatkan mutu dan kualitas dari sumber daya manusia, sehingga mampu mengidentifikasikan dirinya sebagai bagian dari permasalahan yang dialami dan berupaya untuk mencari alternatif pemecahan masalah yang dihadapi. Kemampuan sumber daya manusia sangat dipengaruhi oleh keberdayaan dirinya sendiri. Oleh karena itu sangat dibutuhkan kegiatan pemberdayaan disetiap kegiatan pendampingan. Suharto (2005 : 93) menguraikan bahwa pendampingan merupakan satu strategi yang sangat menentukan keberhasilan program pemberdayaan masyarakat, selanjutnya dikatakannya pula dalam kutipan Payne (1986) bahwa pendampingan merupakan strategi yang lebih mengutamakan "making the best of the client sresources". Keterlibatan masyarakat sebagai sumber daya manusia untuk memberdayakan dirinya, merupakan potensi untuk mencapai tujuan masyarakat, yaitu darimasyarakat, oleh masyarakat dan untuk masyarakat.

Secara teknis pelaksanaan pendampingan, disesuaikan dengan tawaran solusi untuk menyelesaikan permasalahan yang ada, yaitu :

1. Metode pendampingan dalam pengembangan dan pengelolaan seni kerajinan berbasis bambu dan batik eco print sebagai cinderamata (souvenir).

2. Metode pendampingan dalam pengembangan dan pengelolaan manajemen sumber daya manusia untuk menyusun rintisan desa wisata kreatif.

3. Metode pendampingan dalam pengembangan untuk perancangan Environment Graphic Design melalui beberapa tahapan dan proses menurut David Gibson (2009 : 34) yang terdiri dalam 3 (tiga) tahapan besar, yaitu: perencanaan, desain dan implementasi dengan melalui teknis pelatihan, pendampingan, dan workshop bagi warga masyarakat Desa Kundisari, dimana sebuah desain atau rancangan dapat dijelaskan sebagai sebuah usaha untuk memformulasikan unsur fisik yang paling objektif dan merupakan tindakan dan inisiatif untuk mengubah karya manusia (Acher 1965, Alexander 1963, Jones 1970 dalam Agus Sachari (2002 : 4)), dimana secara garis besar perancangannya meliputi 3 (tiga) tahapan, yaitu sebagai berikut :

a. Tahapan Identifikasi Masalah (Envisioning Phase)

b. Tahapan Perencanaan (Planning Phase)

c. Tahapan Desain/Rancangan (Developing Phase)

Tahapan pengabdian kepada masyarakat dapat dilihat dari bagan alur, seperti dibawah ini :

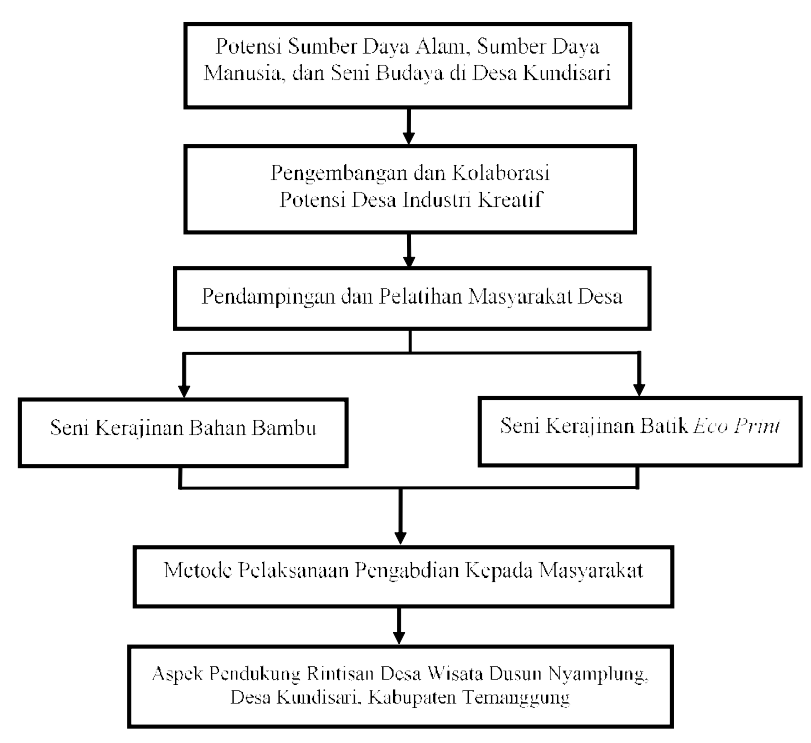

Bagan 1. Kerangka Alur Pengabdian Kepada Masyarakat

\section{E. Pelaksanaan Pengabdian Kepada Masyarakat}

Solusi permasalahan yang diperlukan Desa Kundisari dalam program pengabdian kepada masyarakat ini yang khusus untuk bertujuan mengembangkan potensi industri kreatif dalam 
rangka mendukung rintisan desa wisata di Desa Kundisari, Kecamatan Kedu, Temanggung. Kegiatan ini meliputi tiga aspek yang sudah dirumuskan sebagai permasalahan yang utama. Metode yang digunakan melalui tahapan, yaitu : Tahapan Observasi, Tahapan Pendampingan, Tahapan Perancangan, dan Tahapan Implementasi.

\section{Pengembangan Industri Kreatif Seni Kerajinan Berbasis Bambu}

Potensi bidang industri kreatif yang bisa diterapkan di desa Kundisari, dimana banyak tumbuh pohon bambu yang di wilayah desa Kundisari bisa sebagai alternatif perancangan souvenir berbahan dari bambu. Bambu yang banyak tumbuh bisa dijadikan materi pembuatan souvenir maupun produk fungsional, berupa lampu hias, hiasan dinding, dan produk fungsional lainnya.

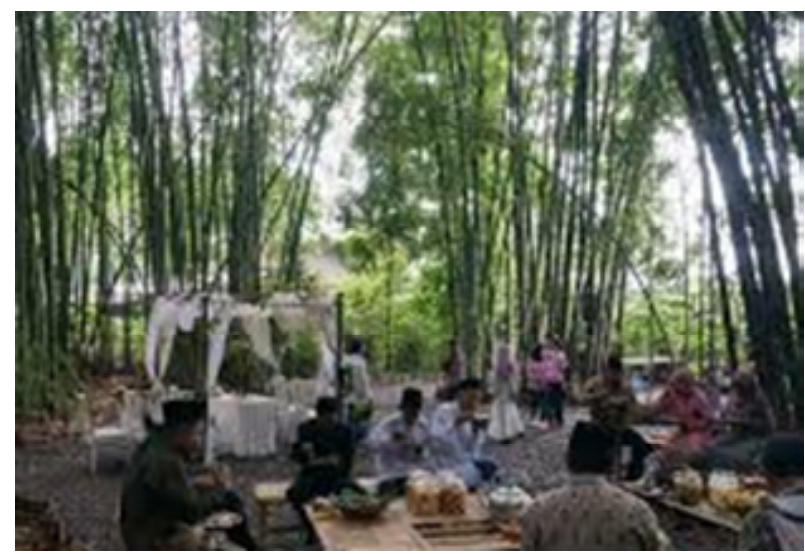

Gambar 1. Tumbuhan Bambu di Pasar Papringan, Temanggung

Sumber: Dokumentasi Kabupaten Temanggung, 2018

Kendala yang dihadapi dalam proses pembuatan kerajinan ini, yaitu antara lain, belum adanya pelatihan dan ketrampilan tentang seni kerajinan bambu, belum adanya kesadaran bagi masyarakat akan potensi yang bisa dikembangkan dari seni kerajinan bambu tersebut, dan belum adanya wahana atau media untuk memasarkan produk kerajinan bambu ke konsumen. Maka kegiatan yang bisa dilakukan adalah melakukan pendampingan kepada masyarakat melalui pelatihan seni kerajinan bambu dengan metode pemaparan, demo, dan praktik langsung. Pendampingan dilakukan di Aula MI Miftahul Fallah, Desa Kundisari, Temanggung dengan peserta wakil dari karang taruna, warga desa dan perangkat desa sekitar 35 peserta yang diadakan selama 3 (tiga ) hari mulai hari Kamis - Sabtu, 9-11 Agustus 2018.

Kegiatan pendampingan yang dibantu oleh mahasiswa KKN ini juga menampilkan metode merancang kerajinan berbasis bambu, melalui bentuk produk asli sehingga peserta akan lebih tahu bentuk nyata dari produk tersebut, produk yang ditampilkan baik di materi presentasi juga berupa prototipe, seperti dalam gambar dibawah ini.

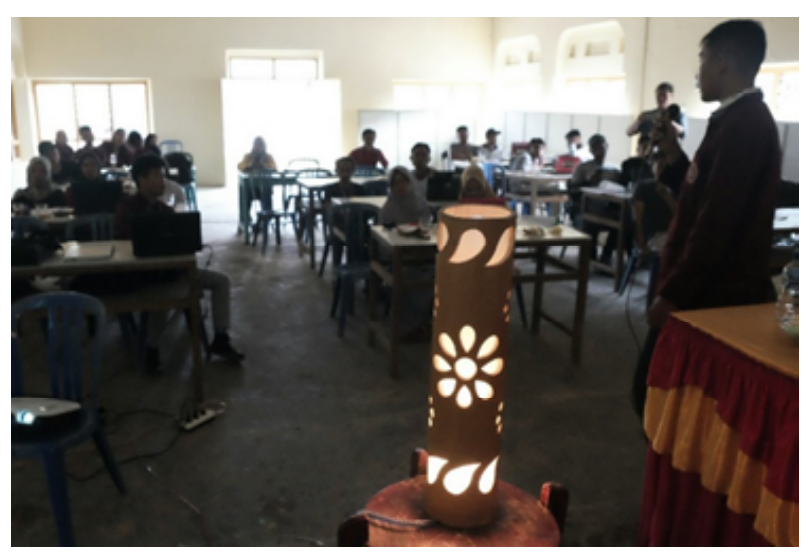

Gambar 2. Prototipe Kerajinan dari Bahan Bambu Berupa Lampu Hias.

Sumber: Dok. Mahasiswa KKN ISI Surakarta, 2018

Tahapan yang harus dilakukan untuk membuat membuat aksesoris interior dari bambu adalah sebagai berikut : pembuatan desain, pemotongan bambu, pengupasan bambu, pengeringan bambu, pengukiran bambu, finishing dan pemasangan lampu. Selanjutnya pelatihan dilakukan dengan praktek langsung merancang kerajinan lampu hias dari bambu. Pelatihan dilakukan dimana peserta langsung praktek dengan pendampingan dari tim mahasiswa KKN sehingga diharapakan peserta dari masyarakat desa Kundisari bisa langsung mengetahui bagaimana proses pembuatan produk tersebut. 


\section{Abdi Seni Jurnal Pengabdian Kepada Masyarakat}

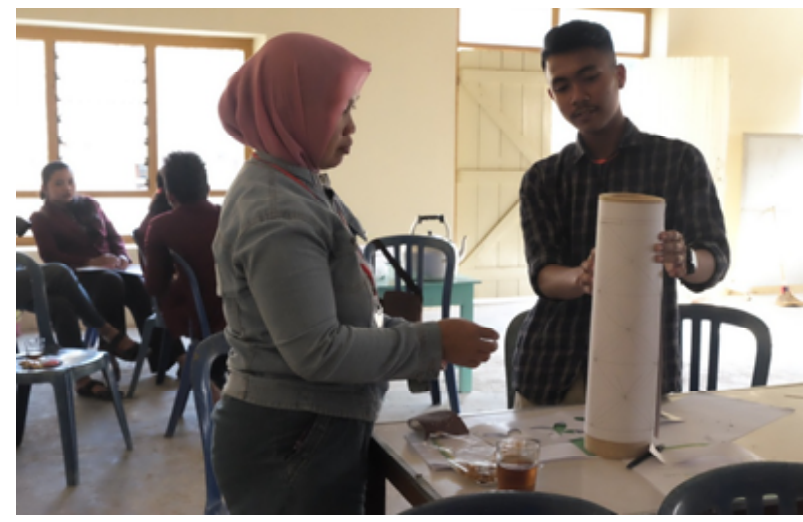

Gambar 3. Proses Membuat Desain Pembuatan Lampu Bambu

Sumber : Dok. Mahasiswa KKN ISI Surakarta, 2018

Pelatihan pada hari pertama pemaparan materi secara umum, pada hari kedua berupa pelatihan membuat desain rancangan lampu hias dari bambu, rancangan diawali dari menggambar pola pada kertas yang sudah disesuaikan dengan ukuran tinggi dan diameter dari bambu yang sudah dipotong.

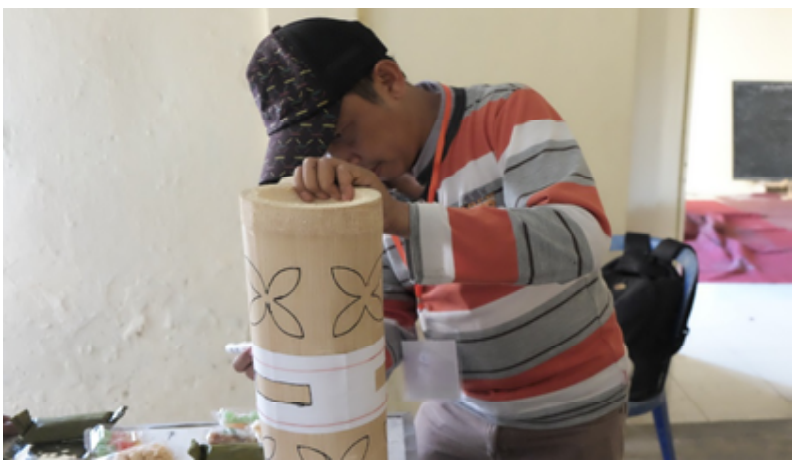

Gambar 4. Proses Membuat Kap Lampu Bambu Sumber : Dok. Mahasiswa KKN ISI Surakarta, 2018

Pelatihan pada hari kedua, proses memotong bagian batang bambu yang sesuai desain sehingga bagian yang dilubangi sebagai tempat sinar lampu. Beragam pola sederhana namun tetap menarik yang diterapkan pada batang bambu membentuk lampu hias yang cukup menarik.

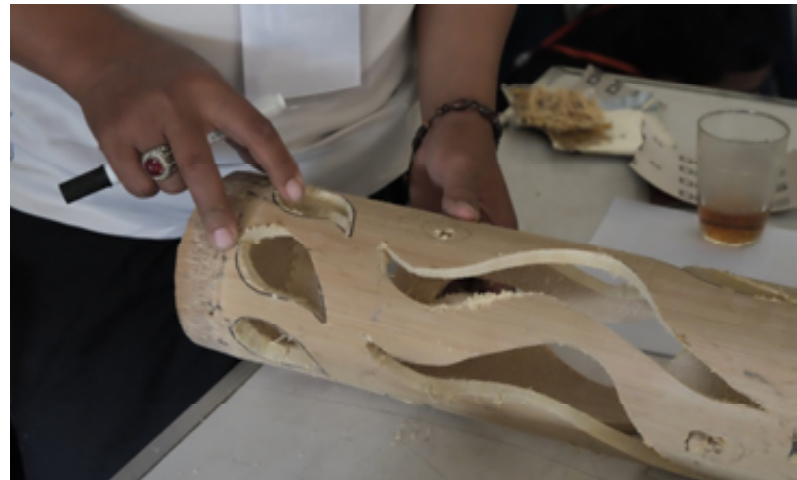

Gambar 5. Proses Pembuatan Kap Lampu dan Tahap Finishing

Sumber : Dok. Mahasiswa KKN ISI Surakarta, 2018

Pelatihan ini bertujuan untuk mendukung rintisan desa wisata di Desa Kundisari, sehingga ada materi produk unggulan serta juga dapat berfungsi sebagai souvenir atau cinderamata yang akan dipasarkan di rintisan desa wisata Desa Kundisari. Hasil pelatihan ini ikut dipamerkan dalam soft launching rintisan desa wisata Kundisari.

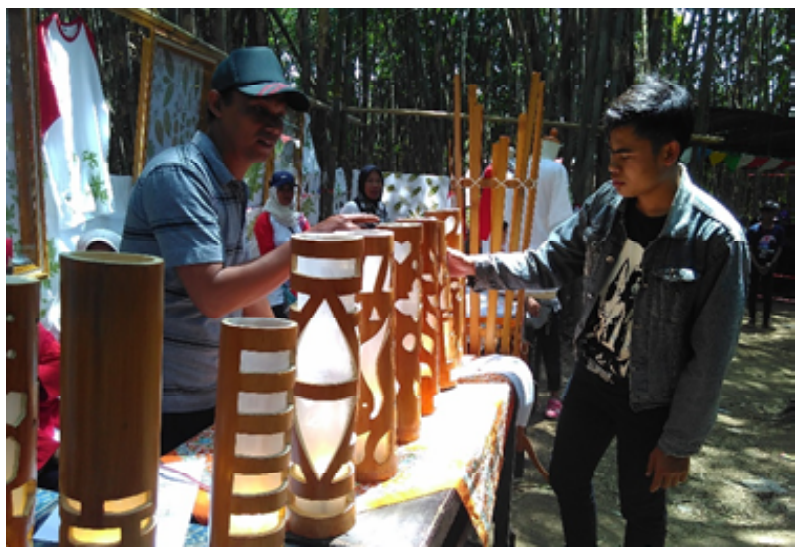

Gambar 6. Produk Kerajian Bambu Hasil Pelatihan Dalam Pameran

Soft Launching Rintisan Desa Wisata Kundisari Sumber : Basnendar H, 2018

Beragam produk kerajinan khusunya berupa lampu hias dipamerkan dan mendapat apresiasi yang cukup bagus sehingga bisa menjadi acuan untuk meningkatkan potensi kerajinan tersebut dengan didukung bahan baku yang melimpah di lokasi wilayah Desa Kundisari. 


\section{PEMBAHASAN}

\section{A. Pengembangan Industri Kreatif Seni Kerajinan Batik Eco Print}

Potensi bidang industri kreatif lainnya yang bisa diterapkan di desa Kundisari, adalah pembuatan batik dengan tehnik eco print, dimana banyak tumbuh-tumbuhan yang ada sehingga bisa digunakan dalam pembuatan batik eco print. Pewarnaan dengan menggunakan unsur-unsur alami ini tidak akan mengakibatkan kerusakan bumi. Teknik alami ini membutuhkan waktu yang lama, tapi disinilah letak keindahannya. Proses pewarnaan alami membuat kita belajar untuk menghargai alam yang telah memberikan kehidupan. Ecoprint disebut unik karena tidak bisa diulang.

Bahan pewarna (daun atau bunga) yang digunakan tidak sama, bahan pewarna yang digunakan di satu tempat dan di tempat lain akan berbeda. Bahkan dua sisi daun yang digunakan pun tidak bisa sama. Beragam produk kerajinan bisa dihasilkan lewat batik eco print dijadikan materi pembuatan souvenir maupun produk fungsional, berupa sarung bantal, kain penutup jendela, produk fashion, dan produk fungsional lainnya. Pelatihan dilaksanakan pada 13 Agustus 2018 dengan peserta sekitar 100 peserta melalui media kain 30 × $30 \mathrm{~cm}$ bertempat di Balai Desa Kundisari.

Ecoprint merupakan teknik cetak yang menggunakan pewarna alami. Teknik sederhana yang tidak melibatkan mesin atau cairan kimia. Teknik ini diaplikasilan pada bahan berserat alami seperti kain kanvas atau katun yang mampu menyerap warna dengan baik. Pencetakan yang ramah lingkungan ini dilakukan dengan menyerap pigmen dari tumbuhan untuk membuat warna yang menarik. Pewarnaan ini dilakukan dengan menimbulkan warna tertentu pada serat selulosa (kapas, linen) atau protein (sutra, wol) tanpa mewarnai benang secara merata. Berbeda dengan teknik pewarnaan yang dilakukan di pabrik dengan menggunakan bahan kimia. Pewarnaan tradisional atau ecoprint ini lebih memanfaatkan tanaman yang tidak dikenal sebagai sumber pewarna. Hasil pencetakan ecoprint ini sangat bervariasi sesuai dengan jenis tanaman, bagian tanaman yang digunakan, waktu pengolahan, tingkat $\mathrm{pH}$, kualitas air, metode pengolahan, jenis serat (selulosa, sintetis atau protein) dan lainnya. Cara yang paling sederhana dilakukan untuk proses ecoprint adalah dengan meletakkan bunga atau daun di atas kain, kemudian memukulnya dengan menggunakan palu. Daun atau bunga akan meninggalkan bekas warna pada kain. Proses sederhana ini tidak membutuhkan waktu lama. Namun hasil pewarnaannya juga akan tetap unik dan menarik.

Kendala yang dihadapi dalam proses pembuatan kerajinan ini, yaitu antara lain, belum adanya pelatihan dan ketrampilan tentang batik eco print, belum adanya kesadaran bagi masyarakat akan potensi yang bisa dikembangkan dari batik eco print, dan belum adanya wahana atau media untuk memasarkan produk ramah lingkungan. Maka kegiatan yang bisa dilakukan adalah melakukan pendampingan kepada masyarakat melalui pelatihan batik eco print dengan metode pemaparan, demo, dan praktik langsung.

Pendampingan dilakukan oleh mahasiswa KKN ISI Surakarta dengan mempertimbangakan situasi dan kondisi dimana peserta yang sebagian besar belum mengetahui dasar-dasar teknik batik eco print, maka pelatihan lebih bersifat dasar dan praktik langsung. Jumlah peserta yang berjumlah sekitar 100 peserta memperlihatkan antusiasme dan minat warga yang khususnya warga perempuan.

Kegiatan pendampingan yang dibantu oleh mahasiswa KKN ini juga menampilkan bagaimana membuat batik dengan mudah melalui teknik eco print, dimana teknik tersebut lebih mudah dilakukan serta penggunaan alat dan bahan bisa didapatkan di lokasi desa tersebut. Pelatihan langsung dengan media bahan kain yang sudah dipotong bujur sangkar dengan ukuran 30 × $30 \mathrm{~cm}$ kepada setiap peserta, kemudian mentor pendamping akan memberi materi disertai demo praktik langsung. Selanjutnya pelatihan dilakukan dan peserta menirukan teknik serta penggunaan alat dan bahan. Pelatihan dilakukan dimana peserta langsung praktek 


\section{Abdi Seni Jurnal Pengabdian Kepada Masyarakat}

dengan pendampingan dari tim mahasiswa KKN sehingga diharapakan peserta dari masyarakat desa Kundisari bisa langsung mengetahui bagaimana proses pembuatan produk tersebut.

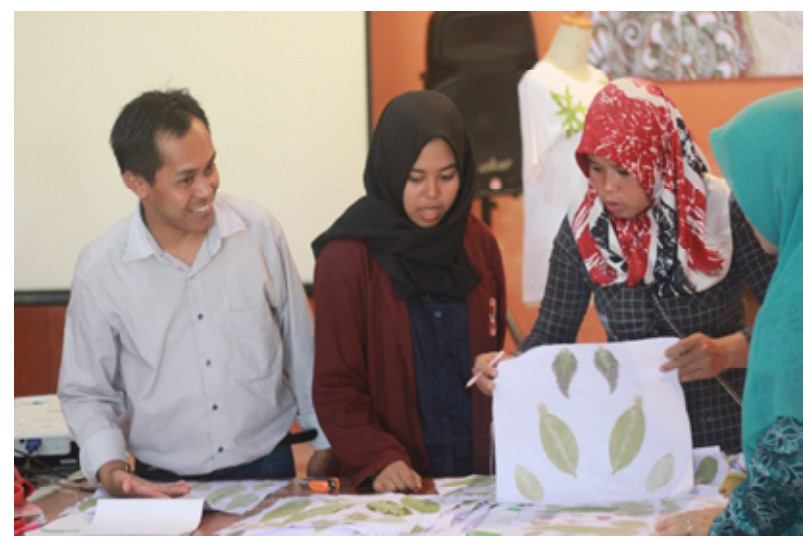

Gambar 7. Praktek Langsung dalam Pelatihan Batik Eco Print

Sumber : Dokumentasi Mahasiswa KKN ISI Surakarta, 2018

Pelatihan yang diperuntukkan kepada warga masyarakat desa maka dipilih metode yang paling mudah dan dapata diterima oleh peserta sehingga masyarakat bisa segera menerapkan pelatihan metode batik eco print.

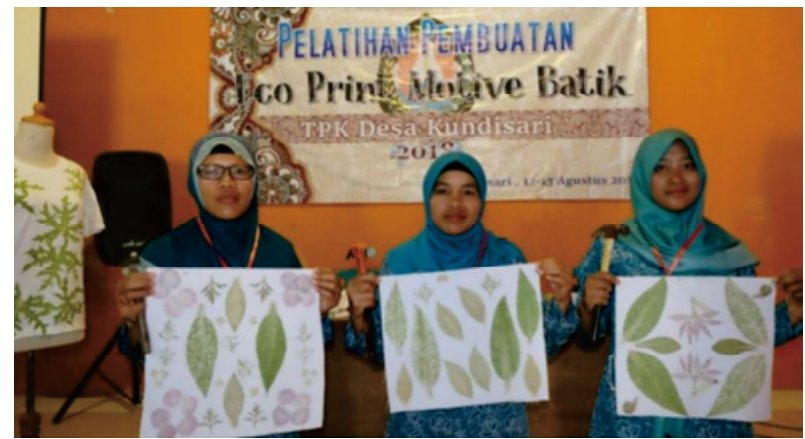

Gambar 8. Peserta Pelatihan dengan Hasil Karya Teknik Batik Eco Print

Sumber : Dokumentasi Mahasiswa KKN ISI Surakarta, 2018

Kegiatan dari beberapa pelatihan untuk warga Desa Kundisari akan diikutsertakan dalam program puncak acara program KKN ISI Surakarta dimana juga untuk memperingati hari kemerdekaan RI tahun 2018 berupa Expo KKN Kundisari di Dusun Nyamplung pada 25 - 26 Agustus 2018, serta sebagai bentuk soft launching rintisan desa wisata Kundisari.

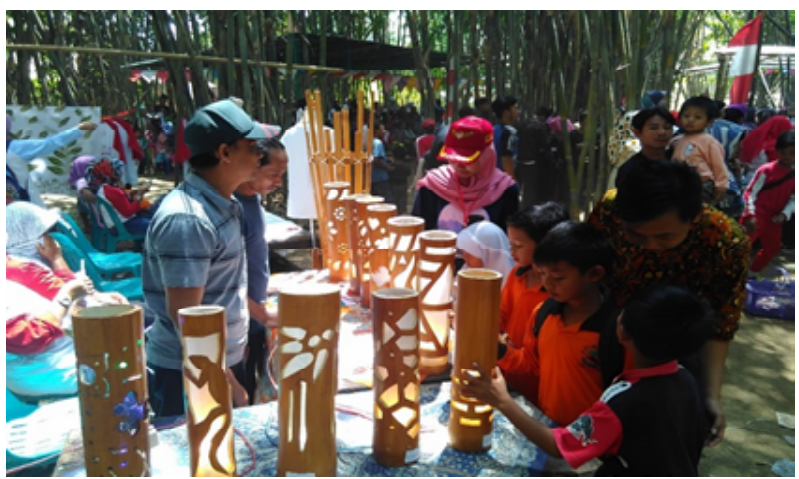

Gambar 9. Hasil Produk Hasil Pelatihan Kerajinan Bambu dalam Expo Kundisari Sumber : Basnendar H, 2018

Event yang cukup meriah berisikan selain pameran produk pelatihan, juga ditampilkan potensi desa berupa gerabah, seni tari, senam lansia, dan seni pertunjukkan lainnya yang dihadiri perwakilan dari UNGRIS (Universitas PGRI Semarang), pejabat desa, kecamatan dan wakil dari Bappeda Kabupaten Temanggung.

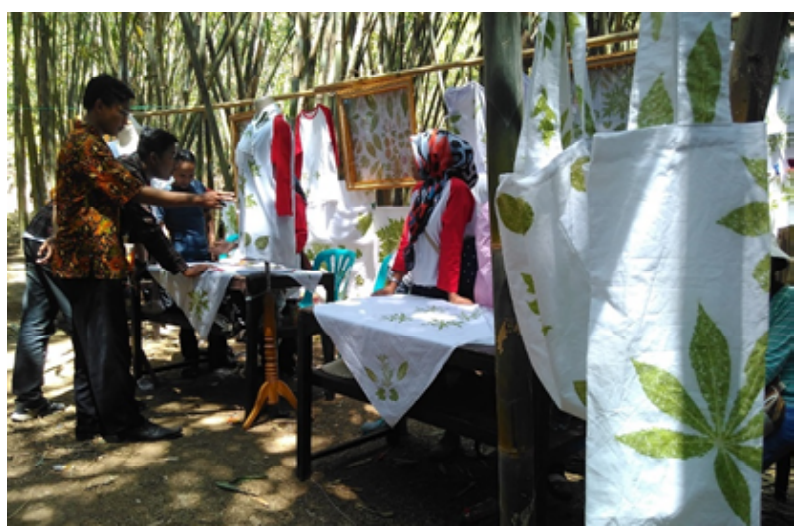

Gambar 10. Hasil Produk Hasil Pelatihan Batik Eco Print dalam Expo Kundisari Sumber : Basnendar H, 2018 
Event ini cukup menarik pengunjung baik dari warga masyarakat maupun dari luar desa dengan lokasi yang sangat potensi sebagai rujukan destinasi baru, berupa desa wisata tematik berbasis industri kreatif.

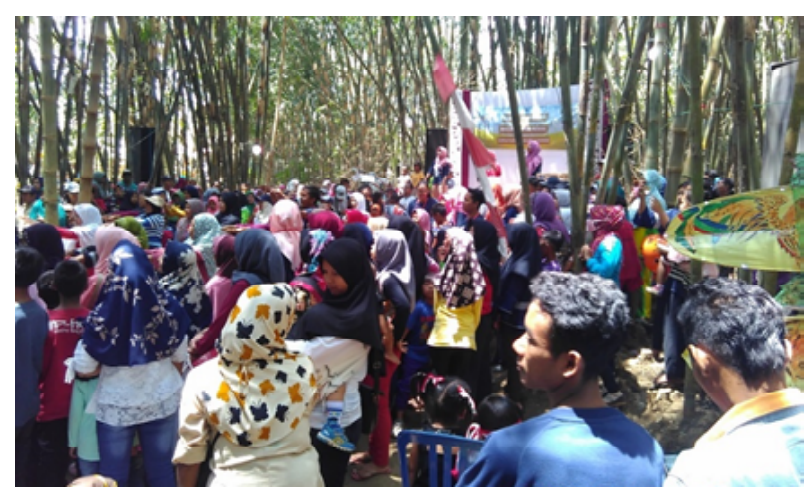

Gambar 11. Suasana dalam Expo Kundisari Dipenuhi Warga Masyarakat Sumber : Basnendar H, 2018

\section{KESIMPULAN}

Pelatihan baik kerajinan bambu berupa lampu hias serta batik teknik eco print inibertujuan untuk mendukung rintisan desa wisata di Dusun Nyamplung, Desa Kundisari, sehingga materi hasil dari pelatihan yang produk unggulan serta juga dapat berfungsi sebagai souvenir atau cinderamata yang akan dipasarkan di rintisan desa wisata tersebut. Pelatihan dengan metode teknologi tepat guna serta bersiafat penerapan teknologi tepat guna ini disesuaikan dengan tingkat pemahaman warga desa melalui praktik langsung sekaligus berlatih mewujudkan produk yang ingin dicapai.

Hasil dari pelatihan ini secara garis besar dapat diterima masyarakat dan produk-produk yang dihasilkan dapat ikut dipamerkan dalam event puncak program KKN yang berlokasi di Dusun Nyamplung bersamaan soft launching rintisan desa wisata. Warga masyarakat dan pejabat pemenrintahan desa sanagat antusias dalam melihat produk hasil pelatihan serta mendukung sekali program sehingga bisa berlangsung dan keberlanjutan di waktu mendatang. Beragam potensi desa, baik yang bersifat sumber daya alam maupun sumber daya manusia bisa menjadi daya pendukung utama sehingga keterlibatan masyarakat untuk memaksimalkan potensi yang ada di wilayahnya dapat dikembangkan serta untuk memajukan baik dari aspek ekonomi, pariwisata maupun aspek lainnya.

Peran serta darimasyarakat, serta pihak lain yang terlibat diperlukan sinergi antar mereka dalam mendukung terwujudnya rintisan desa wisata yang sebagai program unggulan Desa Kundisari. Sinergitas pihak kampus dan akademisi dalam mendukung program pelatihan kepada masyarakat dalam rangka pengembanganpotensi desa di bidang industri kreatif sangat diperlukan, khususnya pelatihan teknologi tepat guna yang nantinya bisa langsung diterapkan oleh warga masyarakat desa. Walau masih banyak kendala yang harus dihadapi, namun program ini bisa menjadi pijakan yang berguna untuk mengawali rintisan desa wisata nantinya. Perhatian dari pemerintah desa, keluraha, kecamatan sampai kabupaten Temanggung tetap dibutuhkan agar program unggulan dari Desa Kundisari bisa berlangung dan berkesinambungan.

Pelatihan ini sebagai stimulan kepada masyarakat, sehingga partisipasi warga desa menjadi point penting dalammewujudkan program unggulan rintisan desa wisata sehingga nantinya dapat terwujud desa wisata yang sesungguhnya. Saran yang bertujuan dalam keberlanjutan program pelatihan ini, baik kepada pihak kampus, warga masyarakat, aparat pemerintahan yaitu senantiasa konsisten dan terus menerus merencankan program yang mendukung desa wisata agar kesejahteraan masyarakat Desa Kundisari dapat meningkat dengan adanya desa wista ini. Selain itu, alokasi waktu dan daya pendukung yang belum maksimal sehingga program pelatihan dalam Program Pengabdian Kepada Masyarakat Tematik ini belum maksimal kepada masyarakat, sehingga diperlukan program berikutnya agar potensi yang ada di desa tersebut bisa lebih berkembang. 
Abdi Seni Jurnal Pengabdian Kepada Masyarakat

\section{DAFTAR PUSTAKA}

Agus Sachari. 2002. Sosiologi Desain, Bandung: Penerbit ITB.

Basnendar Herryprilosadoso, dkk. 2007. Identitas Visual Desa Wisata Batik Cokrokembang Melalui Environment Graphic Design Sebagai Pengembangan di Kabupaten Pacitan. Acyinta, Jurnal Penelitian Seni Budaya, Volume 9. No. 1 Juni 2007, ISSN: 20852444.

Edi Suharto,. 2005. Membangun Masyarakat Memberdayakan Rakyat. Bandung. PT Refika Aditama.

Gibson, David. 2009. The Wayfinding Handbook, Information Design for Public Places. . PrincentonArchitectural Press. New York. Inskeep, Edward, 1991. Tourism Planning An Integrated and Sustainable Development Approach, 1 Edition, John Willey Publishing.

Nuryanto Adhi, 2016. dkk. Perencanan Dan Perancangan Desa Wisata Kampung Tajur Kahuripan di Kab. PurwakartaJawa Barat Berbasiskan Arsitektur Tradisional Sunda. Makalah Seminar Nasional Arsitektur SCAN UAJYYogyakarta
Oka Yoeti.1996. Pengantar Ilmu Pariwisata. Bandung : Angkasa

Payne, Malcolm. 1986. Social care in The Community. London: MacMillan.

Ranang AS, Basnendar H, dan Asmoro NPA, 2010. Animasi Kartun, dari Analog Sampai Digital, Penerbit PT. Indeks, Jakarta, ISBN 979-062-149-3

Sapta Nirwandar. 2014. Building WOW, Indonesia Tourism and Creative Industry, Jakarta, Gramedia Pustaka Utama.

Soetarso Priasukmana dan R. Mohamad Mulyadin. 2001. Pembangunan Desa Wisata: Pelaksanaan Undang-Undang Otonomi Daerah, Motto : Back to Village, Act Locally, Think Globally. Jurnal I N F O S O S I A L E K O N O M I. Vol. 2 No.1.

The Association of Registered Graphic Designers of Ontario. 2010. Access Ability: A Practical Handbook On Accessible Graphic Design. RGD Ontario.

Wiendu Nuryanti. 1993. Concept Perspectiveand Challenges. Makalah bagian dari Laporan Konferensi Internasional mengenai Pariwisata Budaya. Yogyakarta: Gadjah Mada University Press. 